\title{
Catching regional development dreams: a study of cluster initiatives as intermediaries
}

\author{
Inessa Laur, Magnus Klofsten and Dzamila Bienkowska
}

\section{Linköping University Post Print}

N.B.: When citing this work, cite the original article.

This is an electronic version of an article published in:

Inessa Laur, Magnus Klofsten and Dzamila Bienkowska, Catching regional development dreams: a study of cluster initiatives as intermediaries, 2012, European Planning Studies, (20), 11, 1909-1921.

European Planning Studies is available online at informaworld ${ }^{\mathrm{TM}}$ :

http://dx.doi.org/10.1080/09654313.2012.725161

Copyright: Taylor \& Francis (Routledge)

http://www.routledge.com/

Postprint available at: Linköping University Electronic Press

http://urn.kb.se/resolve?urn=urn:nbn:se:liu:diva-80106 


\section{Catching Regional Development Dreams: A Study of}

\section{Cluster Initiatives as Intermediaries}

INESSA LAUR*, MAGNUS KLOFSTEN* \& DZAMILA BIENKOWSKA*

*Department of Management \& Engineering, Division of Project, Innovation \&

Entrepreneurship and HELIX VINN Excellence Centre, Linköping University, Linköping,

Sweden

Correspondence Address: Inessa Laur, Department of Management \& Engineering, Division of Project, Innovation \& Entrepreneurship, Linköping University, SE-581 83 Linköping, Sweden. Email: inessa.laur@liu.se 


\begin{abstract}
This paper focuses on actors and activities of cluster initiatives which are intermediaries within clusters of similar and related firms. A case study method is used; the cases show that their success and longevity depend to a large extent on their actors sharing a common vision. It is proposed that actors involved in cluster initiatives can be categorised according to a typology consisting of key players, target and support groups. Managing cluster initiatives requires striking a balance between well-developed and anchored targeted activities and experimental activities exploring future needs. This requires some openness and flexibility within the shared vision. Cluster initiatives can therefore be viewed as dream-catchers that rather than control and govern the clusters perform a more subtle role of gathering and visualizing potential opportunities in regional contexts and articulating and realizing them through an entrepreneurial process.
\end{abstract}

KEYWORDS Cluster initiatives, intermediaries, cluster development, regional actors, entrepreneurial networks 


\section{Introduction}

Clusters are concentrations of interconnected firms and organisations which are considered as important engines for economic growth and wealth creation (Lundvall \& Borras, 1997; Porter, 2000; Mills et al., 2008). They include different types of actors that both compete and cooperate with regard to technologies and markets (Johannisson et al., 2007). Firms and organisations within clusters benefit from linkages and networks that provide such resources as knowledge, business information, and shared infrastructure (Groen, Van Der Sijde \&Walsh, 2002; Johannisson et al., 2002; Johannisson \& Lindholm Dahlstrand 2009; Bienkowska et al., 2011). These linkages and networks can be formalized and developed within intermediary organizations such as cluster initiatives (Ahedo, 2004; Mattsson, 2009; Hassen et al., 2011). Through leadership and channelling resources they contribute to the increased efficiency of clusters and therefore could accelerate the growth and competitiveness of regions (Ketels et al., 2008; Waxell \& Malmberg 2007; Wincent et al., 2012). Similar arguments can be found in the triple-helix model, in which universities, firms, and governmental agencies interact to create innovation in knowledge-based economies (Etzkowitz \& Klofsten, 2005; Pickernell et al., 2007; Ylinenpää, 2009).

Within cluster initiatives there are various types of actors that have different roles and relationships to each other (Aziz \& Norhashim, 2008; Teigland \& Lindqvist 2007). The reason for participation in cluster initiatives might also vary between actors (van der Sijde $e t$ al., 2011). Furthermore, the form and degree of participation of actors may change over time due to change in their needs. As intermediaries, cluster initiatives are without the traditional relationships with customers and suppliers, rather they move between the various stakeholders to serve their needs (Huggins, 2000; Sölvell et al., 2003; Aziz \& Norhashim, 2008).

In network literature there is an extensive knowledge about both the roles as well as relationships between actors involved in organizational networking and networks (Håkansson, 
1989; Johannisson et al., 2002; Gulati et al., 2000). The networks and clusters fields of research seem to be closely linked (Forsman \& Solitander, 2003). However, the nature of roles and relations is underemphasized in cluster research in general, including cluster initiatives (Royer et al., 2009; Brown et al., 2008).

We believe that studying these aspects is of great importance due to the interest from both researchers and practitioners regarding the role of clusters and cluster initiatives in regional development. Therefore, the focus of this paper is to expand our understanding of cluster initiatives as intermediaries. A particular aim of this study is to investigate activities organized by cluster initiatives as well as to create a typology of the involved actors.

\section{Theoretical Framework}

This study deals with cluster initiatives which we define as a type of intermediary organisation working in a cluster setting. In the following we present these three concepts, starting with the underlying phenomenon of a cluster. Thereafter we combine the literature on intermediaries and cluster initiatives in order to further our understanding of how these organisations operate.

The cluster concept builds on Marshall (1921), who introduced the concept of industrial districts, which are areas with concentrations of a large number of small businesses resulting from their closeness to resources, technical complementarities, and beneficial physical conditions. These firms compete and cooperate. Dahmén (1950) described similar phenomena, calling them development blocks. The concept of development blocks centres on entrepreneurial activities leading to innovations that create such complementarities as interdependency among the functions of institutions, infrastructures, and production.

Porter (1998) introduced the concept of clusters, which influenced such other studies of regional development and economic growth as Clarke et al. (2002), Park \& Lee (2004), 
Oakey (2007), Glavan (2008), and Sövell (2009). Porter (2000, p. 253) defined a cluster as 'geographic concentrations of interconnected companies, specialized suppliers and service providers, firms in related industries, and associated institutions (e.g. universities, standard agencies and trade associations) in particular fields that compete but also cooperate.' There has been some debate over the years concerning whether clusters are exclusively selforganised phenomena or whether they can be created through policy interventions. A majority among the research community argue that most attempts to create clusters have failed or been slow at delivering expected results and that it is not a fruitful policy strategy (Cooke \& Huggins, 2003; Ketels \& Memedovic, 2008). However, where a self-organised cluster already can be observed, actors can strengthen it through such actions as development of education \& training infrastructures; boosting sophisticated local demand or straightening out governmental regulations.

Another possible way of enhancing an existing cluster is to work together in a cluster initiative, which can be started by either public or private organisations. Cluster initiatives can be defined as "collaborative actions by groups of companies, research and educational institutions, government agencies and others, to improve the competitiveness of a specific cluster [... for example] by raising the awareness of companies within a cluster and creating more effective platforms for interaction [... or providing] a platform for a better dialogue between the private and the public sector when making decisions about how to improve the cluster-specific business environment." (Ketels \& Memedovic, 2008, p. 384). The main driving forces behind cluster initiatives are often ambitious and entrepreneurial individuals from the public sector, the private sector, or both (Klofsten \& Jones-Evans, 1996; Lundequist \& Power, 2002; Ketels et al., 2008). Relying on the identification of system gaps and business needs, these individuals launch cluster initiatives in order to satisfy those needs and to fill those gaps (Brown, 2000; Teigland \& Lundqvist, 2007; Aziz \& Norhashim, 2008). In most 
cases they involve themselves in launching the initiatives and then continue to lead them throughout their life-cycles (Klofsten, 2010).

\section{Intermediaries: Activities and Actors}

We propose that cluster initiative can be viewed as a type of intermediary organisation which is in place to articulate and serve the needs of those cluster actors who choose to become associated with it. Some previous studies have noted the similarities between cluster initiatives and intermediaries (Ahedo, 2004; Intarakumnerd, 2005; Teigland \& Lindqvist, 2007; Fromhold-Eisebith \& Eisebith, 2008; Visser \& Atzema, 2008; Zhang \& Li, 2010). Using existing knowledge on intermediaries and their characteristics opens up interesting perspectives in the study of cluster initiatives and casts new light on their activities and relations between involved actors.

In a broad sense, intermediaries are organizations that emerge to perform such middleman services as brokering, facilitating, promoting, and other value-adding activities between actors (Lundequist \& Power, 2002; Van der Meulen et al., 2005; Moss, 2009). Intermediating involves reciprocal exchanges among an intermediary organization and at least two other actors. The force driving the creation of such organizations, as in other entrepreneurial initiatives, is a perceived need or a systemic gap (Chiesa \& Chiaroni, 2004).

In their activities intermediaries can for example focus on knowledge transfer (Smedlund, 2006), financial and technological assistance (Zhang \& Li, 2010), the development of trust and of idea and information exchanges (Johannison \& Nilsson, 1989; Intarakumnerd, 2005; Inkinen \& Suorsa, 2010), facilitating easy access to workers and competencies in general (Benner, 2003), or combinations of these.

Other examples of activities intermediaries perform include providing educational and technical support, building partnerships and brokering agreements between stakeholders, 
facilitating the dissemination of resource-saving technologies, and making actors more visible in the market (Moss, 2009). Bessant \& Rush (1995) mention identifying and articulating certain needs, selecting options, and creating business cases and links to external information. Inkinen \& Suorsa (2010) highlight supporting creation of innovation, disseminating information, and facilitating collaboration.

\section{Methodology}

The empirical basis for this article consists of in-depth interviews combined with an examination of operational manuals, evaluation reports, and other documents describing the cluster initiatives' activities. We used an interactive case study approach (Svensson et al., 2007), where the interview respondents gave a constructive feedback on the content and formulations of research and interview questions, interview responses, and analysis.

We selected four Swedish cluster initiative cases for this study. The basic strategy behind selection of the cases was to capture variation between initiatives from different regions, industries and sizes. Since we were interested in following their development over time, all selected cases have operated or have been operating for a minimum of five years. The in-depth and interactive character of the interviews was dependent on the cooperativeness of the respondents, and out of a list of fifteen possible cases we were granted complete access to the four cases investigated here.

Data was collected through telephone interviews in 2011. A key individual for each cluster initiative was identified and interviewed, these selected individuals are all central in the management of the respective cluster initiative and have been in that position during a substantial part of the cluster initiative's existence. Each initial interview was composed of 16 open-ended questions and took approximately 90 minutes. They covered four themes: a)

general information about the initiatives and the respondents; b) stakeholders and their role in 
the initiatives; c) development of cluster initiatives over time; d) intermediary activities performed by the initiative itself and by the involved actors. Additionally, follow-up interviews were conducted to confirm the results from initial interviews as well as collect additional information. In total ten interviews were conducted during the course of this project.

\section{Results and Analysis}

In the following section the results from the case studies are presented and analysed. Activities and actors are specifically highlighted. A summary of the results is shown in Table 1 below.

\section{Cluster Initiatives: Empirical Context}

Here follows an introduction to the four case studies used in this paper.

RockCity is a cluster initiative founded by a musician and his friends in 1996 as a result of their common interest in music and a shared vision of establishing musical festivals in Sweden's rural Hultsfred district. It currently functions on the basis of close collaboration among micro firms specializing in music and media, Linnaeus University, and the Hultsfred Municipality. RockCity became a positive influence for the region by attracting leading rock bands and festival visitors from all over the world and by providing music-oriented education and training to local people (Hallencreutz \& Lundequist, 2003).

SMIL was launched by employees of Linköping University’s industrial liaison office and entrepreneurs in the university's club for members of former spinoff firms in 1984. The aim of SMIL's founders was to develop themselves as better managers and to boost interest in entrepreneurship. The SMIL network, supported by the university and the Centre of Innovation and Entrepreneurship (CIE), has subsequently developed a portfolio of highly 
Table 1. Characteristics of cluster initiatives

\begin{tabular}{|c|c|c|c|}
\hline Cases & General mission \& location & Intermediating activities & Actors involved \\
\hline RockCity & $\begin{array}{l}\text { Establish music-oriented activities } \\
\text { in the region. Launched in } 1996 \text { in } \\
\text { the small town of Hulsfred, } \\
\text { Sweden. }\end{array}$ & $\begin{array}{l}\text { Organizing festivals. Providing informal } \\
\text { networking meeting places for people and micro } \\
\text { firms in the music sector. Linking actors to create } \\
\text { partnerships. Facilitating education and training. }\end{array}$ & $\begin{array}{l}\text { Micro firms occupied in music } \\
\text { activities. } \\
\text { Regional university and other } \\
\text { business-intermediating } \\
\text { organizations. }\end{array}$ \\
\hline SMIL & $\begin{array}{l}\text { Business development for } \\
\text { knowledge-intensive firms on local } \\
\text { arena. Started in } 1984 \text { in the } \\
\text { medium-sized town of Linköping, } \\
\text { Sweden. }\end{array}$ & $\begin{array}{l}\text { Education and training for entrepreneurs within } \\
\text { knowledge-intensive firms. Such informal and } \\
\text { formal networking activities as seminars, } \\
\text { workshops, and providing meeting places. } \\
\text { Facilitating knowledge exchanges between } \\
\text { academia and firms. }\end{array}$ & $\begin{array}{l}\text { Knowledge-intensive SMEs. } \\
\text { Regional university. Academic and } \\
\text { business intermediating } \\
\text { organizations. }\end{array}$ \\
\hline TIME & $\begin{array}{l}\text { Promotion of the Stockholm area's } \\
\text { ICT industry. Active from } 1999 \text { to } \\
2004 \text {. }\end{array}$ & $\begin{array}{l}\text { Organizing and funding marketing events intended } \\
\text { to promote the Stockholm area's ICT industry. } \\
\text { Attracting investment to the industry. Labour- } \\
\text { market matchmaking. Monitoring members' } \\
\text { performance. }\end{array}$ & $\begin{array}{l}\text { Small, medium, and large ICT firms. } \\
\text { The Stockholm Municipality and } \\
\text { other public intermediating } \\
\text { organizations. }\end{array}$ \\
\hline UppsalaBIO & $\begin{array}{l}\text { Developing the medium-sized town } \\
\text { of Uppsala, Sweden's life science } \\
\text { industry by collaboration among } \\
\text { academia, firms, health-care } \\
\text { institutions, and local authorities. } \\
\text { Launched in } 2003 \text {. }\end{array}$ & $\begin{array}{l}\text { Facilitating knowledge exchanges between } \\
\text { academia and firms in the life science industry. } \\
\text { Supporting the commercialization of ideas by new } \\
\text { and established firms within the industry. } \underline{\text { Such }} \\
\text { networking activities as a yearly conference on } \\
\text { cross-disciplinary life science applications. } \\
\text { Monitoring members' performance. }\end{array}$ & $\begin{array}{l}\text { Small, medium, and large firms in the } \\
\text { life science industry. } \\
\text { Regional universities and institutes. } \\
\text { The Uppsala Municipality, regional } \\
\text { public hospital, and business } \\
\text { intermediating organizations. }\end{array}$ \\
\hline
\end{tabular}


recognized activities designed to promote the growth and development of knowledgeintensive firms (Klofsten \& Jones-Evans, 1996).

TIME started in 1999 following the initiative of a project manager employed by Stockholm City Council driven by an intention to develop the Stockholm area's telecommunications, IT, and media-technology sector and to attract new investors. TIME focused on organization of marketing campaigns in order to create a strong brand for these industries in Stockholm. It organized campaigns, conferences, exhibitions, and other events with financial support from Stockholm City. The TIME initiative was a time-limited project and was incorporated into Kista Science City in 2004.

UppsalaBIO was created by employees of Pharmacia and Uppsala University in 2003 in order to develop life science industry in the region. Its efforts are focused on facilitating efficient knowledge transfer between academia and industry as well as on supporting the commercialization of ideas within that industry (Waxell \& Malmberg, 2007).

\section{Cluster Initiatives' Intermediary Activities}

The data reveal that the studied cluster initiatives perform a wide variety of intermediary activities. They all began based on a basic idea that remained at the centre of further activity development. SMIL, for example, began with a mission to stimulate technology-based firms' business development and over the years developed several activities designed to address the target group's real needs based on this initial idea. It has even broadened its target group to include knowledge-intensive firms in order to address better the needs of that emerging group of entrepreneurs coming out of academic contexts. Similar developments also occurred in the three other cases, which developed both their activities and target groups over the years. 
RockCity's main focus is on organizing festivals, although it also performs such activities as partnerships and education in support of music-industry development in the region. SMIL's core activity is business development and networking through education and training for knowledge-intensive firms. It also organizes knowledge exchanges and informal networking events for a broader audience. TIME focused specifically on the promotion of ICT firms in the Stockholm area, for example through a yearly event called "TIME-week", as well as informal discussion meetings and planning workshops. UppsalaBIO focuses on developing the local life science industry by supporting commercialization and further business development. It also arranges such networking and knowledge exchange events as annual conferences.

An important aspect of activities organised by the cluster initiatives that has emerged in our study is the degree of openness within the provided activities. We could observe that all studied cluster initiatives work to serve both their target groups' needs with specific activities and the needs of the broader community which they address with open house types of activities. Table 2 illustrates examples of these two types.

Table 2: Specific and open house activities of cluster initiatives

\begin{tabular}{|c|c|c|}
\hline $\begin{array}{l}\text { Cluster } \\
\text { initiative }\end{array}$ & Specific target group activities & Open house activities \\
\hline RockCity & $\begin{array}{l}\text { Creating partnerships and facilitating education } \\
\text { within music sector }\end{array}$ & Festivals and common lunches \\
\hline SMIL & $\begin{array}{l}\text { Business development activities for knowledge- } \\
\text { intensive firms, e.g. training and networking }\end{array}$ & $\begin{array}{l}\text { Networking and knowledge exchange } \\
\text { activities, e.g. pub evenings and seminars }\end{array}$ \\
\hline TIME & $\begin{array}{l}\text { Marketing activities and labour-market } \\
\text { matchmaking for the Stockholm area's ICT } \\
\text { industry }\end{array}$ & $\begin{array}{l}\text { Workshops for marketing campaigns and } \\
\text { informal discussion meeting }\end{array}$ \\
\hline UppsalaBIO & $\begin{array}{l}\text { Commercialization and business development } \\
\text { activities, e.g. providing training and } \\
\text { networking for Uppsala's life science industry }\end{array}$ & $\begin{array}{l}\text { Networking and knowledge-exchange } \\
\text { activities, e.g. seminars and annual } \\
\text { conferences }\end{array}$ \\
\hline
\end{tabular}


The amount of time cluster initiatives devote to specific and open house types of activities depends on their contexts. RockCity's and TIME's activities, for example, have usually been more open to public participation, while UppsalaBIO and SMIL offer more targeted activities designed particularly for specific segments of their target groups.

\section{Actors and Roles}

Not surprisingly, cluster initiatives' operations and development are shaped by the involved actors. Their involvement is a combination of mutual interests and a common vision of the cluster initiative's future development. Cluster initiatives also result from perceived gaps between competencies of existing actors and their need for development through training, education, and meeting places. In some cases these gaps might have been noticeable for years before the actual launch of the cluster initiative. The actors could have been addressing them previously with informal collaborations and reciprocal support. A cluster initiative might provide stability and critical mass when dealing with those gaps and needs.

We have observed that actors involved in cluster initiatives can be categorised into three major groups. Firstly, in all cluster initiatives there is a target group which is the main focus for the mission and activities as exemplified by the following statements from the cluster initiatives.

"SMIL is a network for knowledge-intensive firms in the Linköping region." (SMIL,

"Uppsala BIO is an independent and not-for-profit actor working to stimulate growth in the life science sector." (UppsalaBio, 2012)

"Rock City - a national meeting place for the entertainment industry" (RockCity, 2012) 
"TIME-Stockholm aims to promote Stockholm as the TIME (Telecom, Information

Technology, Media and Entertainment) capital.” (Stockholm City Council, 2000)

As could be seen above, target groups can be delimited both in sectorial terms and to specific regional domains. The cluster initiatives approach their target groups aiming to enlist them as members, identify their real needs and on this basis create attractive activities.

Secondly, each cluster initiative also has members that can be described as target group's supporters, such as other intermediary organizations, the public sector, and academia. For example, UppsalaBIO explain their mission in this way:

"We bring together the universities, companies, healthcare, and society to blaze new paths that advance the sector's international competitiveness." (www.uppsalabio.com) Specific examples of organisations belonging to the support groups of cluster initiatives include Sweden's Employment Agency (TIME), the Swedish University of Agricultural Sciences (UppsalaBIO), and representatives of the Linköping Municipality (SMIL).

Thirdly, each initiative also has a key player which has a crucial role in terms of sustaining the continuous survival and development of the cluster initiative. The key player provides stability and a resource base while also having a possibility to influence the operative as well as strategic level of the cluster initiative. By way of example, SMIL cluster initiative has a formal agreement with its key player (the regional university) with a provision for administrative, financial, and human resources support. At RockCity the municipality of Hultsfred has a similar role, as does a foundation for cooperation among Uppsala's universities, business sector, and community called STUNS in the case of UppsalaBIO.

Besides the key player, there are actors within both target and support groups which can exert influence on the operations of the cluster initiatives through for example representation on cluster initiatives' boards, financing activities, and due to having a high degree of trust among other actors. These can be called "core actors" as they are active within the cluster 
initiative and contribute with their time and effort. "Non-core actors" are consequently more passive members of both target and support groups which for example participate in activities but on irregular basis. Over time, actors can transfer from being a non-core to a core actor and vice-versa, depending on their situation and needs. For example, in the case of SMIL it is not unusual that firms that have not participated in any activities for years become more active members due to a shift in circumstances, e.g. management change, new ownership or a forthcoming exit.

\section{Discussion}

Cluster initiatives are arenas for networking and exchanges between different types of private and public organizations. An established common vision is their basis for engaging stakeholders in various intermediating activities that both address the specific needs of their target groups and offer general open house style events.

The development of activities involves segmenting the target group and creating various networking activities for broader audiences, in some cases even including nonmembers. Such segmentation of specific target-group activities seems to fit various needs better based on the target-group firms' maturity, as the needs of start-up firms and established businesses differ (Klofsten \& Jones-Evans, 1996). Another distinction is between supporting ideas with the potential to be commercialized and implementing them.

Other activities involve cluster initiatives opening themselves to the broader community in their areas in order to provide themselves with greater legitimacy and visibility and to attract new members into both their target and support groups. They can achieve this with general open house style activities targeting public and private actors not necessarily currently involved in their cluster initiatives. Striking a balance between being relevant for the members and being open to new perspectives is crucial for the success of cluster initiatives 
(c.f. Eisingerich et al., 2010).

Enthusiastic and engaged individuals with a shared vision are important both when it comes to launching and developing the cluster initiatives. Certain individuals have been successful in reaching out and enrolling all the actors crucial for the initiatives' formation and development. They have created common visions that have convinced those whom they have enrolled of the benefits for them of participating and remaining engaged long-term. Shane \& Venkataraman (2000) considered this to be an entrepreneurial process of discovering and exploiting opportunities for new value-adding activities for the members.

Cluster initiatives seem to depend for their survival on enthusiasts keeping them relevant and valuable by constantly keeping an eye on both target and support groups' changing needs and adjusting their activities accordingly. As Klofsten \& Jones-Evans (1996) found, enthusiastic leaders are centrally important for successful university-industry cooperation. It is equally important for them to review and fine-tune the shared vision continually in order to serve the members' current and evolving needs.

\section{Typology of Actors in Cluster Initiatives}

Figure 1 illustrates the three categories of cluster-initiative members that this study has identified. These are key players, support groups, and target groups. Key players are supporting actors with a dominant position as a result of having, for example, organizing roles, financing roles, or both. They work closely with the actual cluster initiatives. In some cases they even share office space or have the same advisory boards. They may also be connected through common leadership and shared employees. 
Figure 1. Actors involved in cluster initiatives

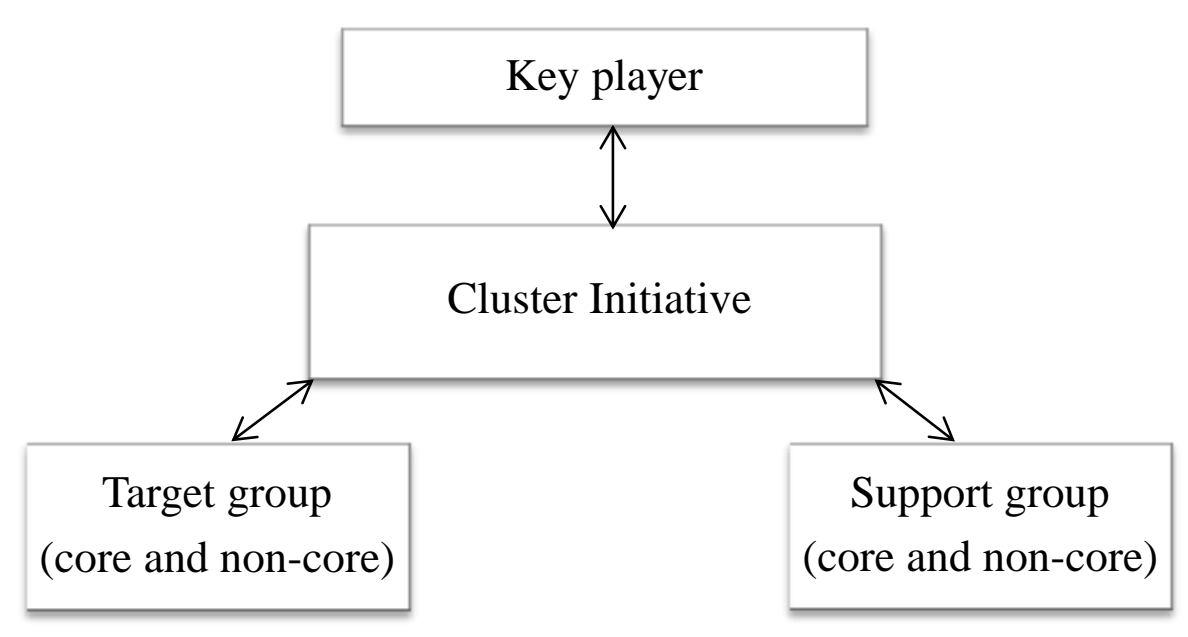

Target groups consist of firms whose needs serve as the basis for the initiative's operations. Whom target groups include tends to vary with the industry, region, and type of business, such as knowledge-intensive firms (Ketels et al., 2008). This highlights the presence of interrelated organizations close to cluster initiatives that share mutual interests and concerns.

Some members of target groups are more influential than others due to having a higher degree of involvement. These are their core actors. The groups' non-core actors participate without necessarily defining their cluster initiatives' on-going activities. Members' needs change over time, however, and organizations can drift from being passive members to being core members and vice versa. One strength of cluster initiatives is therefore that they can cater to their target groups' changing needs (van der Sijde et al., 2011). They can also offer valueadding activities that suit both non-core and core actors.

Support groups consist of such organizations related to target group firms but having different kinds of missions as governmental organizations, academic institutions, regional development agencies, and service firms. They tend to consider involvement in cluster 
initiatives as a way of achieving their own goals, such as social and economic development, university-industry outreach, and finding new clients.

Members of support groups tend to contribute such additional resources to their cluster initiatives as knowledge, financing, and organization-building capacity. Having certain support organizations on board can sometimes increase an initiative's chances of influencing the local political agenda, the national one, or both.

As with target groups, support groups have both core and non-core actors. Their core actors are usually heavy contributors of the resources necessary for running the initiative. They influence their initiatives in various ways, e.g. through documenting the results that their intermediary activities achieve. In some cases the initiative is required to develop indicators for monitoring the progress of target-group firms. Non-core support actors can follow the cluster initiative's development from a distance and commit their resources when specific needs arise.

All of the cluster initiatives studied for this paper developed progressively from initial ideas to portfolios of both general and specific value-adding activities. A clear connection exists between the development of activities and the actors involved playing different roles. Cluster initiatives intermediate by listening and capturing their target group networks' evolving needs and then mobilizing resources and developing and organizing activities in cooperation with their key players to address those needs.

\section{Conclusions and Implications}

Cluster initiatives play an important role in regional development through their ability to connect actors on a voluntary basis and create activities based on the real needs of their stakeholders (Johannison \& Lindholm Dahlstrand, 2009; Moss, 2009; Carayannis \& Borowik, 2010). As proposed here, cluster initiatives can be viewed as intermediaries between three 
categories of actors. These are (a) key players, who have a critical role as resource providers and a dominant position in setting their agendas and who stand as guarantees of continuity and long-term commitment, (b) target groups, which are a prerequisite for identifying businesses' real needs and achieving high-quality intermediating activities, and (c) support groups, which increase the value of the initiatives' intermediating activities through their competence, networks, and political and societal influence.

When managing cluster initiatives it is important to be able to find a balance between running well-developed and well-anchored targeted activities and experimental activities that explore future needs. Even though cluster initiatives' members value catering to a quite welldefined target group there should also be room for activities involving broader audiences. These could result in an unexpected cross-fertilization of resources, ideas, and opportunities. It might therefore be fruitful to remain informal to some extent and keep a certain degree of openness.

Cluster initiatives' success is highly dependent on the presence of a shared vision that enthusiastic people work to realize. This is highly similar to the entrepreneurial process and should be allowed to grow and develop on its own terms. It is necessary for cluster initiatives to be sensitive to their stakeholders' constantly changing needs and to adapt to them actively. It is therefore appropriate to view cluster initiatives as dream-catchers that gather and visualize potential opportunities that are not yet articulated, as 'the entrepreneur is a human dream catcher who plucks the vapour of ideas from the future, gives them substance, and inspires other to bring them to life' (Macdonald, 2007, p. 53).

Policy makers supporting cluster initiatives should allow them a high degree of freedom and be aware of the challenges involved in sticking exactly to the initial plan and in measuring their activities' results and impact. New measuring tools that reflect this 'unruly process' (Mattsson, 2007, p. 34) may enable them to do this. Therefore, we should be aware 
that promotion of cluster initiatives needs to sustain certain informalities to avoid hampering the entrepreneurial spirit of involved stakeholders.

\section{Acknowledgements}

The authors want to thank HELIX VINN Excellence Centre for financial support of this study. Many thanks to the anonymous reviewers who gave valuable comments to improve the quality of the paper. Finally, we are grateful to the interview respondents for providing access to data.

\section{References}

Ahedo, M. (2004) Cluster policy in the basque country (1991-2002): Constructing 'industrygovernment' collaboration through cluster-associations, European Planning Studies, 12(8), pp. 1097-1113.

Aziz, K. \& Norhashim, M. (2008) Cluster-based policy making: Assessing performance and sustaining competitiveness, Review of Policy Research, 25(4), pp. 349-375.

Benner, C. (2003) Labor flexibility and regional development: The role of labor market intermediaries, Regional Studies 37(6-7), pp. 621-633.

Bessant, J. \& Rush, H. (1995) Building bridges for innovation: The role of consultants in technology transfer, Research Policy, 24(1), pp. 97-114.

Bienkowska, D., Lundmark, M. and Malmberg, A. (2011), Brain Circulation and Flexible Adjustment: Labour Mobility as a cluster advantage. Geografiska Annaler: Series B, Human Geography, 93(1), pp. 21-39.

Brown, K., Burgess, J., Festing, M., Royer, S., Steffen, C. \& Waterhouse, J. (2008) Single firms and competitive advantage in clusters - Context analysis identifying the embeddedness of a winery in the Hunter Valley, in: M. Festing \& S. Royer (Eds) Current issues in international human resources management and strategy research, pp.12-26. München: Schriftenreihe Internationale Personal - und Strategieforschung.

Brown, R. (2000) Cluster dynamics in Theory and Practice with Application to Scotland, Regional and Industrial Policy Research Paper no 38, Glasgow: European Policies Research Centre, University of Strathclyde.

Carayannis, E. \& Borowik, I. (2010) Forms and role of cluster initiatives in fostering innovation in post-industrial regions: a comparative study of environmental technologies clusters in the British West Midlands and the Spanish Basque Country, International Journal of Innovation and Regional Development, 3(3-4), pp. 222-253.

Chiesa, V. \& Chiaroni, D. (2004) Industrial clusters in biotechnology: Driving forces, development processes and management practices, River Edge, NJ: World Scientific Publishing Co.

Clarke, S., Meranto, O. \& Kehl, J. (2002) The CO-CA cluster: Initiatives for preparing future faculty, Political Science and Politics, 35(4), pp. 720-725. 
Cooke, D. \& R. Huggins (2003) High-Technology Clustering in Cambridge (UK), in: F. Sforzi (Ed) The Institutions of Local Development, pp. 51-74, Aldershot (UK): Ashgate Publishing.

Dahmén, E. (1950) Swedish industrial organizations: Causal analysis of industrial development, 1919-1939. Stockholm: Stockholm Industrial Research Institute.

Eisingerich, A., Bell, S. \& P. Tracey (2010) How can clusters sustain performance? The role of network strength, network openness, and environmental uncertainty, Research Policy, 39(2), pp. 239-253.

Etzkowitz, H. \& Klofsten, M. (2005) The innovating region: Toward a theory of knowledgebased regional development, $R \& D$ Management, 35(3), pp. 243-255.

Forsman, M. \& Solitander, N. (2003) Network knowledge versus Cluster Knowledge - The Gordian Knot of Knowledge Transfer Concepts, Working Paper no 494, Helsingfors: Hanken School of Economics.

Fromhold-Eisebith, M. \& Eisebith, G. (2008) Looking behind facades: Evaluating effects of (automotive) cluster promotion, Regional Studies, 42(10), pp. 1343-1356.

Glavan, B. (2008) Coordination failures, cluster theory, and entrepreneurship: A critical view, Quarterly Journal of Austrian Economics, 11(1), pp. 43-59.

Groen, A., Van Der Sijde, P. \& Walsh, S. (2008) Introduction: Entrepreneurship's role in commercializing disruptive technologies, International Small Business Journal, 26(1), pp. 5-7.

Gulati, R., Nohria, N. \& Zaheer, A. (2000) Strategic networks, Strategic Management Journal, 21(3), pp. 203-215.

Hallencreutz, D. \& Lundequist, P. (2003) Spatial clustering and the potential for policy practice: Experiences from cluster-building processes in Sweden, European Planning Studies, 11(5), pp. 533- 564.

Hassen, T.B., Klein, J. \& Tremblay, D-G. (2011) Building local nodes in a global sector: Clustering within the aeronautics industry in Montreal, Canadian Geographer / Le Géographe canadien, 55(4), pp. 439-456.

Huggins, R. (2000) The success and failure of policy-implanted inter-firm network initiatives: Motivations, processes and structure, Entrepreneurship \& Regional Development, 12(2), pp. 111-135.

Håkansson, H. (1989) Corporate technological behavior. Cooperation and networks, London: Routledge.

Inkinen, T. \& Suorsa, K. (2010) Intermediaries in regional innovation systems: Hightechnology enterprise survey from northern Finland, European Planning Studies, 18(2), pp. 169-87.

Intarakumnerd, P. (2005) The roles of intermediaries in cluster development: The Thai experiences from high-tech and community-based clusters, Asian Journal of Technology Innovation, 13(2), pp. 23-43.

Johannisson, B., Caffarena, L., Cruz, A., Epure, M., Pérez, E., Kapelko, M., Murdock, K., Nanka-Bruce, D., Olejárová, M., Lopez, A., Sekki, A., Stoian, M.-C., Tötterman, H. \& Bisignano, A. (2007) Understanding the industrial district: Contrasting conceptual images as a road to insight, Entrepreneurship \& Regional Development, 19(6), pp. 527-554.

Johannisson, B. \& Lindholm Dahlstrand, A. (2009) Bridging the functional and territorial rationales-Proposing an integrating framework for regional dynamics, European Planning Studies, 17(8), pp. 1117-33.

Johannisson, B. \& Nilsson, A. (1989) Community entrepreneurs: Networking for local development, Entrepreneurship \& Regional Development, 1(1), pp. 3-19. 
Johannisson, B., Ramírez-Pasillas, R. \& Karlsson, G. (2002) The institutional embeddedness of local inter-firm networks: A leverage for business creation, Entrepreneurship \& Regional Development, 14(4), pp. 297-315.

Ketels, C., Lindqvist, G. \& Sölvell, Ö. (2008) Clusters and cluster initiatives, Stockholm: Center for Strategy and Competitiveness, Stockholm School of Economics.

Ketels, C. \& Memedovic, O. (2008) From clusters to cluster-based economic development, International Journal of Technological Learning, Innovation and Development, 1(3), pp.375-392.

Klofsten, M. (2010) Generella framgångsfaktorer i kluster: En studie av entreprenörskap och innovation, Linköping: HELIX Excellence Centre, Linköping University.

Klofsten, M. \& Jones-Evans, D. (1996) Stimulation of technology-based small firms - A case study of university-industry cooperation, Technovation, 16(4), pp. 187-193.

Lundequist, P. \& Power, D. (2002) Putting Porter into practice? Practices of regional cluster building: Evidence from Sweden, European Planning Studies, 10(6), pp. 685-704.

Lundvall, B.-A. \& Borras, S. (1997) The globalising learning economy: Implications for innovation policy, Brussels: European Commission.

Macdonald, R. (2007) Beat the system: 11 secrets to building an entrepreneurial culture in a bureaucratic world, London: John Wiley \& Sons.

Marshall, A. (1921) Principles of economics, London: McMillan.

Mattsson, H. (2007) Locating biotech innovation: places, flows and unruly processes, Geografiska regionstudier, 73. Uppsala: Department of Social and Economic Geography.

Mattsson, H. (2009) Innovating in cluster/cluster as innovation: The case of the Biotechvalley cluster initiative, European Planning Studies, 17(11), pp. 1625-.

Mills, K., Reynolds, E. \& Reamer, A. (2008) Clusters and Competitiveness: A New Federal Role for Stimulating Regional Economies, Washington, DC: The Brookings Institution.

Moss, T. (2009) Intermediaries and the governance of sociotechnical networks in transition, Environment and Planning, 41(6), pp. 1480-1495.

Oakey, R. (2007) Problems with regional development planning: The case of clustering, Manchester: Manchester Business School.

Park, S.C. \& Lee, S. (2004). The regional innovation system in Sweden: A study of regional clusters for the development of high technology, AI \& Society, 18(3), pp. 276-292.

Pickernell, D., Rowe, P., Christie, M. \& Brooksbank, D. (2007) Developing a framework for network and cluster identification for use in economic development policy-making, Entrepreneurship \& Regional Development, 19(4), pp. 339-358.

Porter, M. (1998) Clusters and the new economics of competition, Harvard Business Review, 76(6), pp. 77-90.

Porter, M. (2000) Location, competition, and economic development: Local clusters in a global economy, Economic Development Quarterly, 14(1), pp. 15-34.

RockCity (2012) Available at www.rockcity.se

Royer, S., Festing, M., Steffen, S., Brown,K., Burgess, J. \& Waterhouse, J. (2009) The Value Adding Web at Work - Developing a toolbox to analyse firm clusters, Danish-German Research Paper No 1, Flensburg: University of Flensburg.

Shane, S. \& Venkataraman, S. (2000) The promise of entrepreneurship as a field of research, Academy of Management Review, 25(1), pp. 217-226.

Smedlund, A. (2006) The roles of intermediaries in a regional knowledge system, Journal of Intellectual Capital, 7(2), pp. 204-220.

SMIL (2012) Available at www.smil.se

Stockholm City Council (2000) Annual Report 2000. Available at www.stockholm.se 
Svensson, L., Ellström, P.-E. \& Brulin, G. (2007) Introduction - On interactive research, International Journal of Action Research, 3(3), pp. 223-250.

Sölvell, Ö. (2009) Cluster: Balancing evolutionary and constructive forces, Second edition, Stockholm: Ivory Tower Publishers.

Sölvell, Ö., Lindqvist, G. \& Ketels, C. (2003) The cluster initiative greenbook, Stockholm: IvoryTower AB.

Teigland, R. \& Lindqvist, G. (2007) Seeing eye-to-eye: How do public and private sector views of a biotech cluster and its cluster initiative differ? European Planning Studies, 15(6), pp. 767-86.

UppsalaBIO (2012) Available at www.uppsalabio.com

Van der Meulen, B., Nedeva, M. \& Braun, D. (2005) Intermediaries Organisation and Processes: Theory and Research Issues. Position Paper for the PRIME Workshop, 6-7 October 2005, Enschede, The Netherlands.

Van Der Sijde, P., Jurjens, P., Pastoor, R., Hiemstra,G. \& Oudshoorn, M. (2011) Acquiring valuable knowledge by organizations: A reversal of the knowledge transfer process. Annual International Conference of High Technology Small Firms, 17-22 June, Manchester, UK.

Visser, E.-J. \& Atzema, O. (2008) With or without clusters: Facilitating innovation through a differentiated and combined network approach, European Planning Studies, 16 (9), pp. 1169-1188.

Waxell, A. \& Malmberg, A. (2007) What is global and what is local in knowledge-generating interaction? The case of the biotech cluster in Uppsala, Sweden, Entrepreneurship \& Regional Development, 19(2), pp. 137-159.

Wincent, J., Thorgren, S. \& Anokhin, S. (2012) Managing Maturing Government-Supported Networks: The Shift from Monitoring to Embeddedness Controls, British Journal of Management, doi: 10.1111/j.1467-8551.2012.00819.x

Ylinenpää, H. (2009) Entrepreneurship and innovation systems: Towards a development of the ERIS/IRIS concept, European Planning Studies, 17(8), pp. 1153-1170.

Zhang, Y. \& Li, H. (2010) Innovation search of new ventures in a technology cluster: The role of ties with service intermediaries, Strategic Management Journal, 31(1), pp. 88109. 